\title{
Article
}

\section{One-Step Liquid Phase Polymerization of HEMA by Atmospheric-Pressure Plasma Discharges for Ti Dental Implants}

\author{
Judit Buxadera-Palomero ${ }^{1,2,3}$, Katja Fricke ${ }^{4, * \mathbb{D}}$, Stephan Reuter $4,5,+\mathbb{D}$, Francisco Javier Gil ${ }^{6} \mathbb{D}_{\text {, }}$ \\ Daniel Rodriguez ${ }^{1,2,3}$ (D) and Cristina Canal $1,2,3, *$ (D)
}

1 Biomaterials, Biomechanics and Tissue Engineering Group, Department of Materials Science and Engineering, Technical University of Catalonia (UPC), Av. Eduard Maristany 10-14, 08019 Barcelona, Spain; judit.buxadera@upc.edu (J.B.-P.); daniel.rodriguez.rius@upc.edu (D.R.)

2 Barcelona Research Center in Multiscale Science and Engineering, UPC, 08930 Barcelona, Spain

3 Research Centre for Biomedical Engineering (CREB), UPC, 08034 Barcelona, Spain

4 Leibniz Institute for Plasma Science and Technology (INP), 17489 Greifswald, Germany; Stephan.Reuter@polymtl.ca

5 Plasma Physics and Spectroscopy Laboratory, Department of Engineering Physics, Polytechnique Montréal, 2500 Chemin de Polytechnique, Montréal, QC H3T 1J4, Canada

6 Bioengineering Institute of Technology (BIT), Universitat Internacional de Catalunya (UIC), 08195 Sant Cugat del Vallès, Spain; xavier.gil@uic.cat

* Correspondence: k.fricke@inp-greifswald.de (K.F.); cristina.canal@upc.edu (C.C.); Tel.: +49-383-4554-3841 (K.F.); +34-934-017-810 (C.C.)

+ At the time of measurements.

check for

updates

Citation: Buxadera-Palomero, J.; Fricke, K.; Reuter, S.; Gil, F.J.; Rodriguez, D.; Canal, C. One-Step Liquid Phase Polymerization of HEMA by Atmospheric-Pressure Plasma Discharges for Ti Dental Implants. Appl. Sci. 2021, 11, 662. https://doi.org/10.3390/app11020662

Received: 5 December 2020 Accepted: 8 January 2021 Published: 12 January 2021

Publisher's Note: MDPI stays neutral with regard to jurisdictional clai$\mathrm{ms}$ in published maps and institutional affiliations.

Copyright: (C) 2021 by the authors. Licensee MDPI, Basel, Switzerland. This article is an open access article distributed under the terms and conditions of the Creative Commons Attribution (CC BY) license (https:// creativecommons.org/licenses/by/ $4.0 /)$.
Featured Application: In this paper, a fast, one-step method to prepare acrylate-based coatings on titanium through the atmospheric pressure plasma polymerization of HEMA is described. The coating shows lower surface bacterial adhesion and enhanced cell adhesion when compared with pristine titanium.

Abstract: Dental implants can fail due to various factors, in which bad tissue integration is believed to have a significant role. Specific properties of the implant surface, such as its chemistry and roughness, are of paramount importance to address specific cell responses, such as the adsorption of proteins, as well as the adhesion and differentiation of cells, which are suitable for biomaterial and tissue engineering. In this study, an acrylate-containing coating was produced on titanium surfaces through the atmospheric pressure plasma treatment of a liquid precursor, 2-hydroxyethyl methacrylate. A hydrophilic coating was obtained, showing retention of the monomer chemistry as assessed by FTIR analysis and XPS. Enhanced fibroblast adhesion and decreased Staphylococcus aureus and Escherichia coli adhesion were recorded, showing that this is a suitable method to produce biocompatible coatings with a reduced bacterial adhesion.

Keywords: atmospheric pressure plasma jet; plasma polymerization; acrylate coating; titanium implants; biocompatible

\section{Introduction}

Dental implants are a common solution to overcome the problem of tooth loss [1]. However, these implants can fail due to various factors, in which the lack of osseointegration-the ingrowth of the implant into the bone structure-and implant-related infections are thought to play a key role [2-5]. The lack of osseointegration can be explained by the implant's mobility, the surface properties of the implant, medical treatments applied to the patient (radiation therapy or pharmacological agents) and the patient's related factors, including osteoporosis, rheumatoid arthritis, renal insufficiency or smoking [6-9]. 
Titanium is widely used to produce dental implants, mainly due to its biocompatibility, corrosion resistance, mechanical properties and low immunogenic potential [10]. Titanium is naturally covered by a titanium oxide layer that facilitates the adsorption of biomolecules, supporting cell adhesion and spreading [1].

Specific properties of the implant surface, such as chemistry and roughness, play a determining role to address specific cell responses (e.g., the adsorption of proteins, as well as the adhesion and differentiation of cells) suitable for biomaterial and tissue engineering. Therefore, various attempts have been made to increase the success rate of implants by tailoring the surface properties, including modification of the topography features [11], doping with inorganic antimicrobial agents [12-18], immobilizing bioactive molecules like antibiotics $[19,20]$ or peptides [21-27] and coating the titanium surface with polymers [28-31].

Plasma polymerization has been widely used as a process for preparing biocompatible coatings, but until recently, the application was limited mostly to low-pressure plasma polymerization [32-34] or, alternatively, with atmospheric pressure plasma polymerization [35-37]. In the latter, either dielectric barrier discharges or plasma jets are employed, introducing monomers in the discharge by producing an aerosol which was led by the gas flow toward the surface of the material [38]. Lately, the interest in atmospheric pressure plasma jets has been growing, as they enable spatially resolved surface treatments, along with the creation of chemically heterogeneous surfaces to foster specific cell-surface interactions.

Atmospheric pressure plasma jets (APPJs) have been used for the treatment of medical devices in order to produce chemically reactive surfaces with different functionalities [39], such as the preparation of carboxyl [39,40] or amino rich surfaces [40], which can be further used for the immobilization of biomolecules like proteins or peptides. Those surfaces have been proven to increase the number of cells adhered on the plasma-treated material. APPJs have also been used to produce antifouling polyethyleneglycol (PEG) coatings by plasma polymerization in order to prepare antithrombogenic materials [41], or as a pretreatment of the substrate to immobilize cell adhesion peptides [42]. When focusing on the titanium dental implants, APPJs have been used as a methodology to render antibacterial surfaces [43] or to sterilize titanium implants [44]. A nanocomposite coating to be used as a drug delivery system, containing silica and poly(lactic-co-glycolide), has also been prepared using this technique, showing increased adhesion of osteoblasts and fibroblasts [45].

Besides that, for the improvement of biocompatibility, nitrogen- or oxygen-containing functional groups are known to support cell attachment and proliferation [46]. Recent developments are focused on the generation of oxygen-rich, hydrocarbon-based polymer coatings by using plasmas for the polymerization of polyethylene glycol, poly $\varepsilon$ caprolactone or acrylic acid to modify cell attachment on a variety of substrates, such as silicon [47,48], polypropylene meshes [49], glass [50] or titanium [51]. Based on the oxygen functional groups present on the surface, ion-ion and ion-dipole interactions occur that favor the attachment of proteins. With respect to dental implants, where suitable cell adhesion is required, especially coatings rich in carboxylic or hydroxyl groups are favored. These coatings can be prepared, for instance, via the polymerization of liquid 2-hydroxyethyl methacrylate (HEMA) at atmospheric pressure by using a plasma jet. So far, grafting of HEMA grafting on dentin [52] and other substrates [53] was reported, but it has not been studied previously on titanium substrates, which might be a fast and easy processing method to obtain biocompatible coatings with reduced bacterial adhesion on dental implants.

Accordingly, the aim of this study is to investigate the polymerization of 2-hydroxyethyl methacrylate (HEMA) in its liquid phase by employing an atmospheric pressure plasma jet and ascertaining whether this could provide suitable properties for titanium surfaces from the standpoint of future clinical applications in dentistry. With this in mind, different 
process parameters have been tested, whereas the coating properties have been analyzed in terms of chemical properties and their biological performance in vitro.

\section{Materials and Methods}

\subsection{Plasma Source and Process Parameters}

A 27.12 Mhz driven atmospheric pressure plasma jet (Figure 1) was used to polymerize HEMA on different substrates [54]. The plasma jet consisted of two ring electrodes around a quartz capillary. The upper electrode was capacitively coupled to the frequency generator, whereas the other one was grounded.

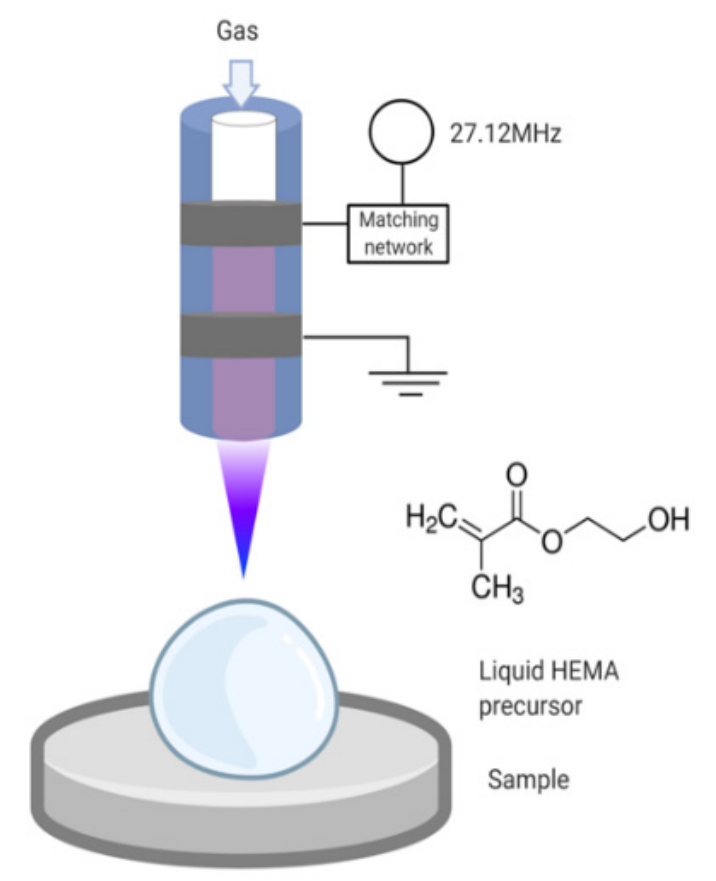

Figure 1. Schematics of the atmospheric pressure plasma jet used in this study, employing Ar as a working gas to polymerize the liquid 2-hydroxyethyl methacrylate (HEMA) monomer on titanium samples or silicon wafers.

The coating was prepared by placing a drop of liquid 2-hydroxyethyl methacrylate (HEMA) directly on the sample surface and treating the liquid with an argon plasma (Figure 1). Parameters such as the plasma input power, Ar flow rate, liquid drop volume and distance between the tip of the glass capillary and the sample were varied in order to investigate the most suitable conditions to obtain the coatings (Table 1).

Table 1. Sample identifier (ID) employed in this work and corresponding process parameters for the generation of HEMA-based coatings.

\begin{tabular}{cccccc}
\hline $\begin{array}{c}\text { Sample } \\
\text { ID }\end{array}$ & $\begin{array}{c}\text { Plasma Input } \\
\text { Power }(\mathbf{W})\end{array}$ & $\begin{array}{c}\text { Ar Gas Flow } \\
(\mathbf{s L M})\end{array}$ & $\begin{array}{c}\text { Distance } \\
(\mathbf{m m})\end{array}$ & $\begin{array}{c}\text { Treatment } \\
\text { Time }(\mathbf{m i n})\end{array}$ & $\begin{array}{c}\text { HEMA Volume } \\
(\boldsymbol{\mu L})\end{array}$ \\
\hline S1 & 10 & 1 & 4 & 5 & 8 \\
S2 & 7 & 0.7 & 4 & 5 & 8 \\
S3 & 10 & 1 & 3 & 5 & 10 \\
S4 & 10 & 1 & 3 & $2.5+2.5$ & $5+5$ \\
\hline
\end{tabular}

\subsection{Materials}

Silicon ( $\mathrm{Si}$ ) wafers (single-side polished, $(<111>)$, N-type phosphorus doped, resistance 1-5 $\Omega \mathrm{cm}$, MicroChemicals, Germany) were cut into substrates of $10 \times 10 \mathrm{~mm}^{2}$, which were used as a model surface for the characterization of the coating. 
Commercially pure titanium (Ti) grade 2 was purchased as rods $10 \mathrm{~mm}$ in diameter (VDM metals, Germany) and cut into $2 \mathrm{~mm}$ disks. Ti samples were ground in a sequence of silicon carbide grinding papers with decreasing particle sizes (P400, P600, P800, P1200, P2500, Neurtek, Spain) and polished with a colloidal silica suspension (Eposil M11, particle size $0.06 \mu \mathrm{m}$, Neurtek). The samples were cleaned in a sequence of solvents-distilled water, ethanol and acetone (Panreac, Germany) — in an ultrasonic bath.

The 2-hydroxyethyl methacrylate at 98\% purity (HEMA) was purchased from Sigma Aldrich (Germany) and used without further purification.

Dulbecco's modified Eagle medium (DMEM, Invitrogen, Carlsbad, CA, USA) supplemented with 10\% fetal bovine serum (FBS, Invitrogen, Carlsbad, CA, USA), 2 mM Lglutamine (Invitrogen), $50 \mathrm{U} / \mathrm{mL}$ streptomycin/penicillin (Invitrogen), phosphate buffered saline (Gibco, UK), a lactate dehydrogenase (LDH) cytotoxicity detection kit (Roche, USA) and a mammalian protein extraction reagent (mPER, Thermo Scientific, USA) were used for biocompatibility assays.

Brain heart infusion (BHI, Scharlab, Spain) and agar bacteriological (Scharlab, Spain) were used for bacterial adhesion assays.

\subsection{Surface Characterization}

\subsubsection{Surface Free Energy}

The contact angles of distilled water, diiodemethane and ethylene glycol were measured at room temperature by the sessile drop method, using an OCA 30 contact angle analyzer (DataPhysics Instruments $\mathrm{GmbH}$ ) and a drop of $1 \mu \mathrm{L}$. The surface free energy was calculated by using the Owens, Wendt, Rabel and Kaelble (OWRK) method [55] with SCA20 software.

\subsubsection{Fourier Transformed Infrared Spectroscopy (FTIR)}

FTIR spectra were acquired in the attenuated total reflectance (ATR) mode, using a diamond crystal and recording 32 scans in the range of $650-4000 \mathrm{~cm}^{-1}$, with Spectrum One equipment (Perkin Elmer).

\subsubsection{X-ray Photoelectron Spectroscopy (XPS)}

XPS spectra were acquired using an Axis Supra DLD electron spectrometer (Kratos Analytical Ltd., Mandhester, UK) with a monochromatic Al K $\alpha$ source (1486.6 eV). Surveyand core-level spectra of $\mathrm{O} 1 \mathrm{~s}, \mathrm{~N}$ 1s, C 1s, Ti 2p and Si $2 \mathrm{p}$ were collected by applying $15 \mathrm{kV}$ and $10 \mathrm{~mA}$ for the survey spectra and core-level spectra, respectively, and $15 \mathrm{kV}$ and $15 \mathrm{~mA}$ for the highly resolved measured C 1s peaks. All XPS measurements were collected with a $250 \mu \mathrm{m}$ spot size, using a charge neutralizer during acquisition. Data processing were carried out using CasaXPS software, version 2.3.22PR1.0 (Casa Software, Ltd., Teingnmouth, UK). Curve fitting of the high-resolution C 1s spectra was also carried out using CasaXPS software. The line shape used was a Gaussian-Lorentzian (GL 30) function with a Shirley background. Due to sample charging, the binding energy scale was corrected for all samples by setting the C 1s binding energy to $285.0 \mathrm{eV}$. Concentrations were provided in atomic percent (at.\%). A depth profile was generated by alternating cycles

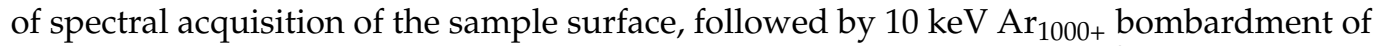
the sample surface. The beam was rastered over an area of $1.5 \times 1.5 \mathrm{~mm}^{2}$.

\subsubsection{Coating Stability}

The stability of the coatings was studied by immersing the coated samples in deionized water for $24 \mathrm{~h}$ and $48 \mathrm{~h}$, or by applying an ultrasonic treatment in water for $5 \mathrm{~min}$. The wettability of each coating was studied by water contact angle measurements, and the chemical composition was assessed by ATR-FTIR and XPS analysis after drying the samples with a nitrogen gas flow. 


\subsection{Biocompatibility Studies}

\subsubsection{Indirect Cytotoxicity}

The indirect cytotoxicity of the samples was evaluated following the ISO 10993-5 standard [56] with human foreskin fibroblasts (hFFs, Merck Millipore Corporation, Bedford, USA). Details on the protocol can be found elsewhere [29]. Briefly, the non-treated and plasma-treated samples were sterilized in ethanol for $10 \mathrm{~min}$, washed three times with Phosphate Buffer Saline (PBS) and immersed in DMEM for $72 \mathrm{~h}$ at $37^{\circ} \mathrm{C}$. The hFFs were cultured at a cell density of $5 \times 10^{3}$ cells/well on a 96 well tissue culture polystyrene (TCPS) plate for $24 \mathrm{~h}$. Dilutions of the sample extracts $(1: 1,1: 10,1: 100,1: 1000)$ were used to incubate the cells for $24 \mathrm{~h}$, and afterward, the cells were lysed with mPER in order to quantify the cell viability with the LDH kit.

\subsubsection{Cell Adhesion}

Cell adhesion assays were performed with hFFs according to the protocol described in [29]. Briefly, $2 \times 10^{4}$ cells per sample in $1 \mathrm{~mL}$ of medium were seeded on the sterilized samples and incubated for $6 \mathrm{~h}$ at $37^{\circ} \mathrm{C}$. After the incubation time, the adhered cells were lysed with $\mathrm{mPER}$, and the viability was quantified with the LDH kit.

\subsection{Bacterial Adhesion}

Bacterial adhesion was performed with Staphylococcus aureus (S. aureus, CCUG 15915, Culture Collection University of Göteborg, Göteborg, Sweden) and Escherichia coli (E. coli, CECT 101, Colección Española de Cultivos Tipo, Valencia, Spain). The protocol followed can be found elsewhere [57]. Briefly, the samples were sterilized by immersion in ethanol and washed three times with PBS. Then, $1 \mathrm{~mL}$ of the bacterial suspension-adjusted to an absorbance of $0.2 \pm 0.01$-was placed on the samples and incubated for $2 \mathrm{~h}$ at $37^{\circ} \mathrm{C}$. Bacteria were detached from the surface and plated on agar plates by serial dilution.

\subsection{Statistical Analysis}

The cell and microbiological results were presented as the average \pm standard deviation of at least three independent samples. Statistical analysis was performed with Minitab $17^{\mathrm{TM}}$ software (Minitab Inc, State College, PA, USA). Data were analyzed by one-way ANOVA tables with Tukey's multiple comparison tests in order to evaluate any statistically significant differences between sample groups. The differences were considered statistically significant when $p<0.05$.

\section{Results}

\subsection{Surface Characterization}

\subsubsection{Surface Free Energy}

For the calculation of the free surface energy of the coatings, the method of Owens, Wendt, Rabel and Kaelble was used, whereby the free surface energy is divided into a polar and a dispersive component. Due to a static plasma treatment and the local confinement of the area that was directly exposed to the plasma, the contact angles were measured on two different positions: one in the center of the coating and the other one in the edge region of the coating. Figure 2 shows the free surface energies of coatings polymerized at different process parameters. The data obtained revealed that the surface free energy were independent of the measurement position and process conditions. Compared to the titanium, all the coated samples showed a higher polar component and thus, in total, an increased surface free energy, revealing that the coating was more hydrophilic. 


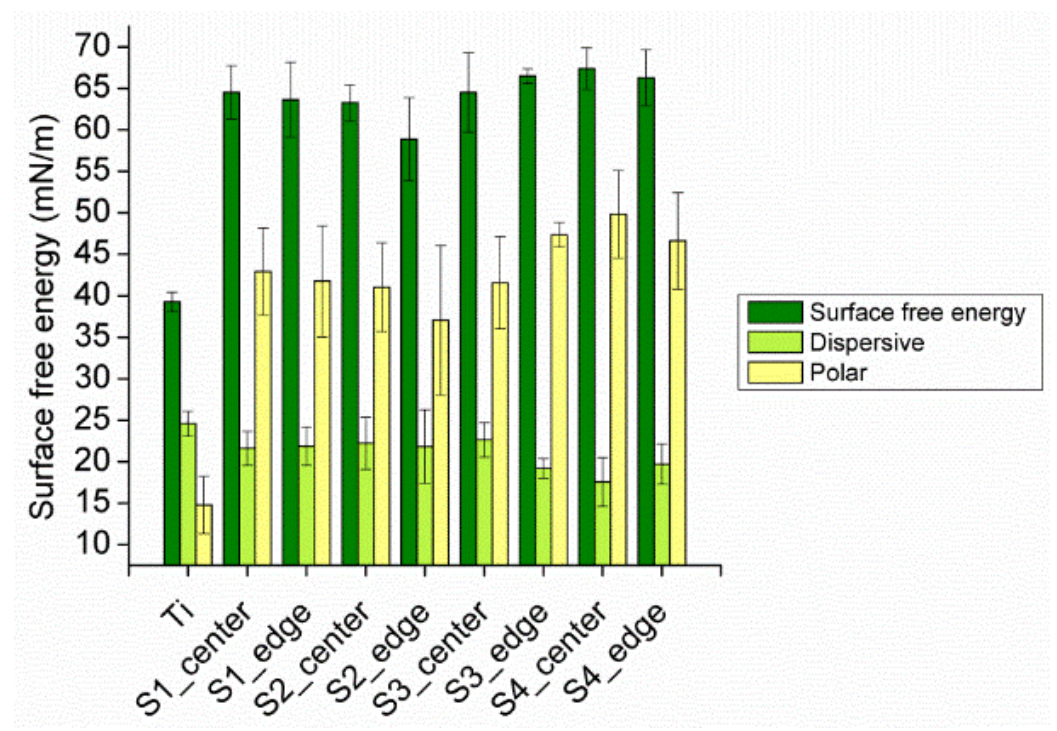

Figure 2. Surface free energy of plasma-polymerized, HEMA-based coatings on Ti samples for different sets of process parameters.

\subsubsection{Chemical Composition}

The chemical compositions of the coatings deposited on the Si wafer was investigated by means of ATR-FTIR (Figure 3a). The bands indentified in the spectra (Figure 3b) corresponded to the characteristic signals found in the liquid precursor, which were the alcohol bands (stretching at $3422 \mathrm{~cm}^{-1}$ and bending at $1022 \mathrm{~cm}^{-1}$ ) and the ester band (stretching $\mathrm{C}=\mathrm{O}$ at $1728 \mathrm{~cm}^{-1}$ and stretching $\mathrm{C}-\mathrm{O}$ at $1275 \mathrm{~cm}^{-1}$ ). While all the coatings showed the main bands associated with a HEMA coating, the S4 coating seemed to have a lower contribution from the $\mathrm{OH}$ band and a higher contribution from the hydrocarbon bands.

a

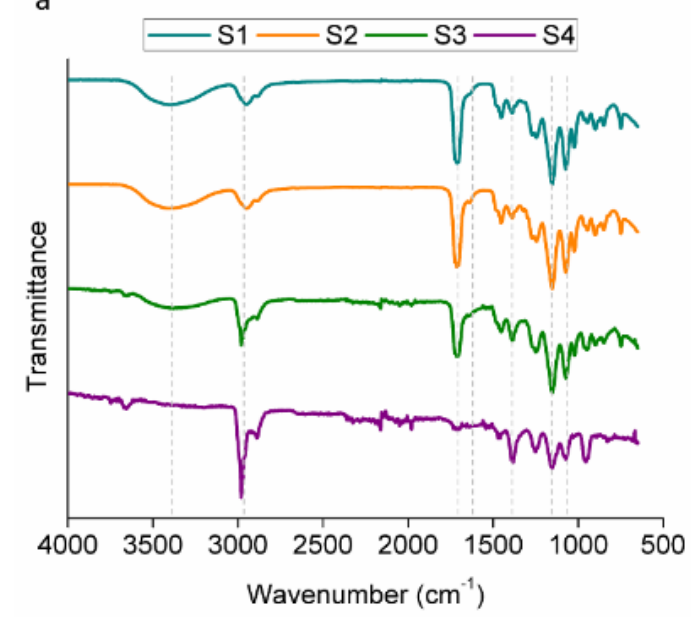

b

\begin{tabular}{cc}
\hline $\begin{array}{c}\text { Wavenumber } \\
\left(\mathrm{cm}^{-1}\right)\end{array}$ & $\begin{array}{c}\text { Peak } \\
\text { assignation }\end{array}$ \\
\hline 3422 & OH stretching \\
3097 & Vinyl stretching \\
$2954-2888$ & C-H stretching \\
1712 & C=O stretching \\
1637 & C=C stretching \\
1160 & C-O stretching \\
1456 & C-H bending \\
1022 & C-O bending \\
\hline
\end{tabular}

Figure 3. (a) Normalized attenuated total reflectance Fourier transformed infrared spectroscopy (ATR-FTIR) spectra of HEMA-based plasma polymer coatings and (b) assignation of the main peaks.

XPS analysis was performed to determine the elemental compositions of the coatings. In particular, a line scan was acquired with a step size of $1 \mathrm{~mm}$ involving the entire coating, as depicted in Figure 4. The elements identified in the survey spectra were carbon (C), oxygen $(\mathrm{O})$, nitrogen $(\mathrm{N})$ and silicon $(\mathrm{Si})$. In comparison with the stoichiometric composition of HEMA (presented as dashed lines), the coatings showed higher portions of carbon and decreased contents of oxygen, especially in the center of the coatings (highlighted in yellow in the graphs). In contrast, the edge regions of the films exhibited fractions of elements close to the theoretical values for HEMA. It can be assumed that, due to the 
plasma treatment, the degree of polymerization was higher in the center, resulting in a more cross-linked coating, and lower in the edge region, where the impact of the plasma effluent was reduced.

A

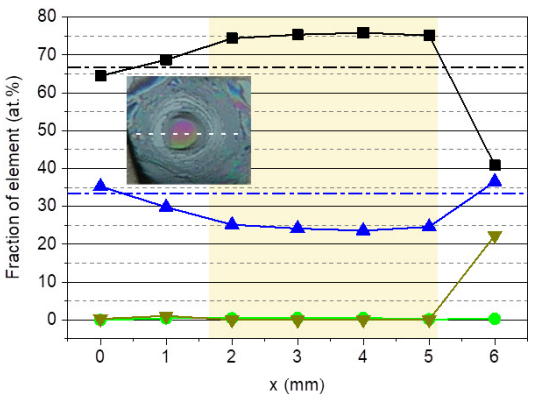

C

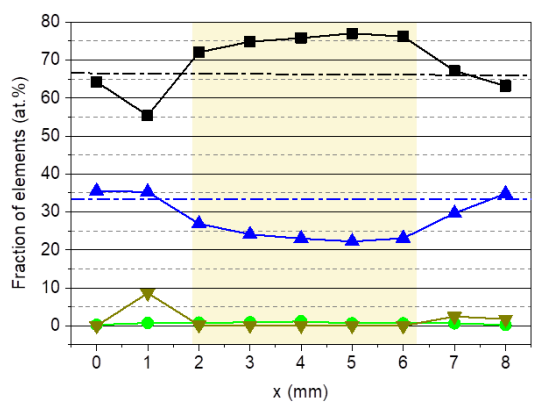

--. C theoretical --. O theoretical

B

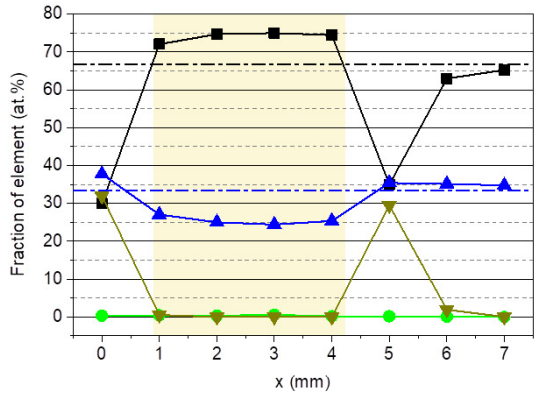

D

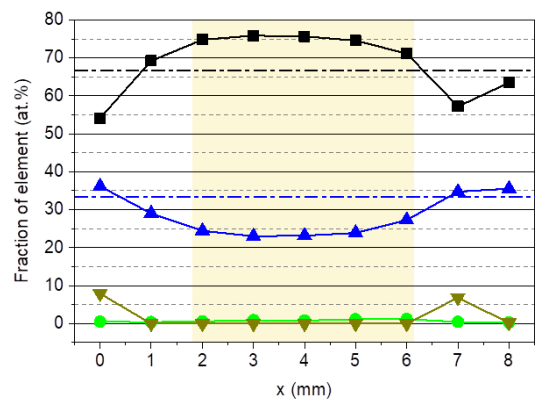

Figure 4. Line scan of the atomic percent concentrations of all elements identified on the sample surfaces S1 (A), S2 (B), S3 (C) and S4 (D). The dashed lines indicate the stoichiometric composition of Poly(2-hydroxyethyl methacrylate (PHEMA). The inset in Figure 4a presents a photograph of the generated coating. The yellow area highlights the center of the coating.

XPS analysis further revealed traces of $\mathrm{N}$, which might be incorporated when operating in ambient air or by post-plasma reactions, as well as $\mathrm{Si}$ in the edge region, which originated from the substrate and indicated a film thickness less than $6 \mathrm{~nm}$.

\subsubsection{Coating Stability}

The stability of the coating was assessed by immersing the samples in water for $48 \mathrm{~h}$. In particular, water contact angle measurements were conducted on the as-deposited coatings and on coatings after being immersed in water (Figure 5). It was found that all the analyzed coatings exhibited lower water contact angles when compared with the pristine Ti. Furthermore, an increase of the water contact angle was observed for all films after immersion in water. This was most likely due to the immersion in water, during which fragments of the non-polymerized HEMA oligomers were removed or, depending of the stability of the coating, thickness losses occurred.

Hence, XPS analysis was conducted to study the chemical composition of the HEMAbased polymer films, depending on storage in air or in water for $24 \mathrm{~h}$ and $48 \mathrm{~h}$, respectively, as well as after $5 \mathrm{~min}$ of ultrasonic treatment in water (Figure 6). The elemental composition was determined on three different spots in the center of the coating. While the coatings stored in water showed no differences compared to the as-deposited coating, the storage in water caused a decrease of the carbon signal and an increase of the oxygen signal. 


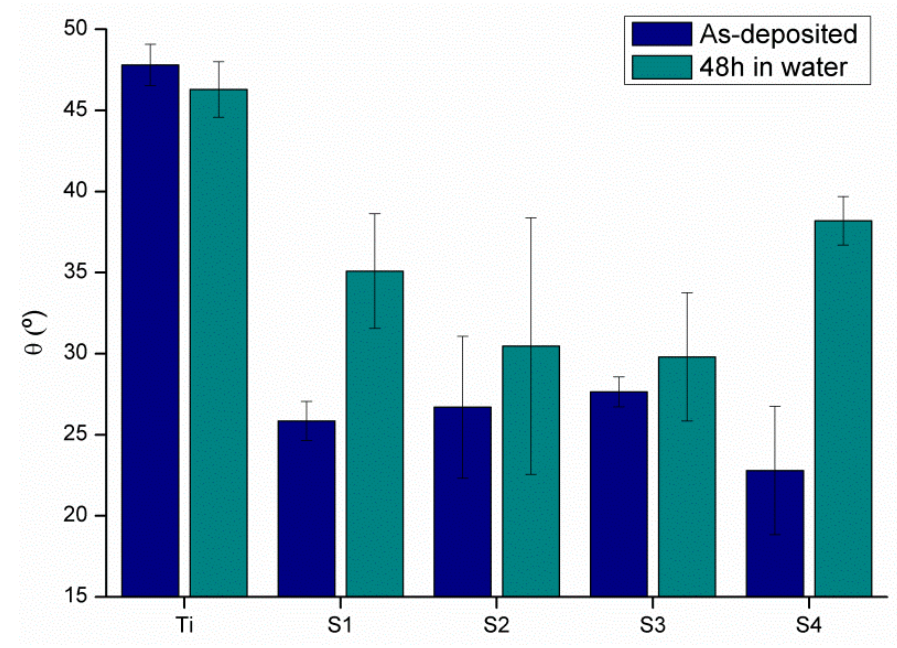

Figure 5. Water contact angle of the coatings as-deposited and after $48 \mathrm{~h}$ of immersion in deionized water.

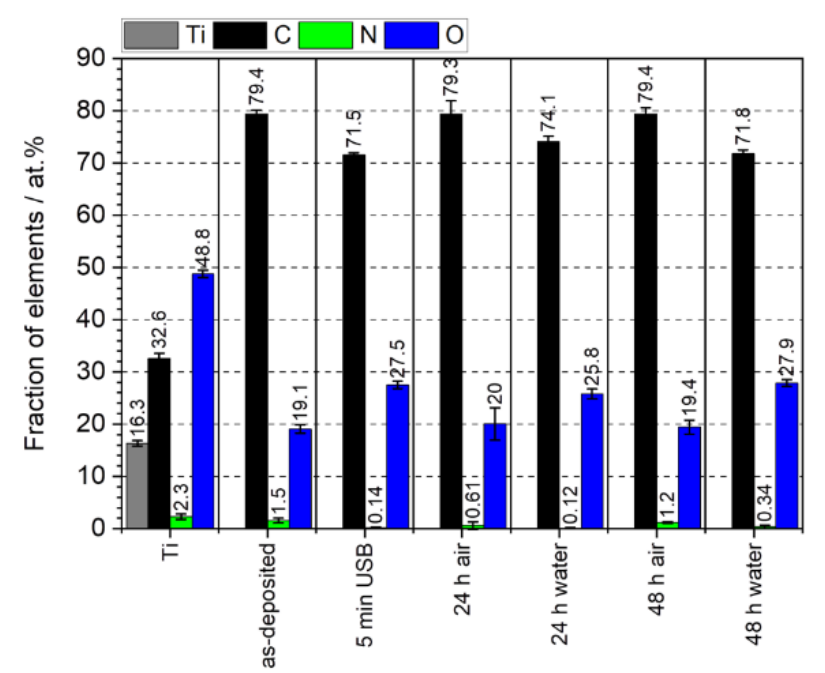

Figure 6. Elemental composition of the plasma-polymerized HEMA coatings as deposited after $5 \mathrm{~min}$ of ultrasonic treatment (USB) and of the coatings being stored in air or water for $24 \mathrm{~h}$ and $48 \mathrm{~h}$, respectively.

High-resolution C 1s spectra of coatings as deposited and after storage in air or deionized water for $24 \mathrm{~h}$ and $48 \mathrm{~h}$ respectively, were fitted with several peaks associated with different chemical species (Figure 7). For the as-deposited film and those stored in air, four componets were assumed, in particular hydrocarbon (i.e., $\mathrm{sp}^{3}, \mathrm{C}-\mathrm{H}, \mathrm{C}(\mathrm{B} . \mathrm{E} .=285.0 \mathrm{eV})$ ), the ether group C-O $($ B.E. $=286.6 \mathrm{eV})$, the carbonyl group C $=\mathrm{O}($ B.E. $=287.8 \mathrm{eV})$ and the ester group O-C $=\mathrm{O}($ B.E. $=289.2 \mathrm{eV})$. The additional peak at B.E. $=285.7 \mathrm{eV}$ was assigned to the secondary $(\beta)$ chemical shift produced by the ester carbon $(4.2 \mathrm{eV}$ primary chemical shift) [58]. In contrast, for the HEMA-based polymer films stored in water, only three functional components were identified which were attributed to hydrocarbon, ether and ester carbon species. Furthermore, the $\mathrm{C} 1 \mathrm{~s}$ spectra showed an increased intensity of the oxygen-containing components when immersed in water. Quantification data derived from the high resolution C 1s spectra are shown in Figure 8. Compared with the values reported in the literature [59], the films immersed in water proved that the poly(HEMA) structure can be retained even after plasma polyermerization. 

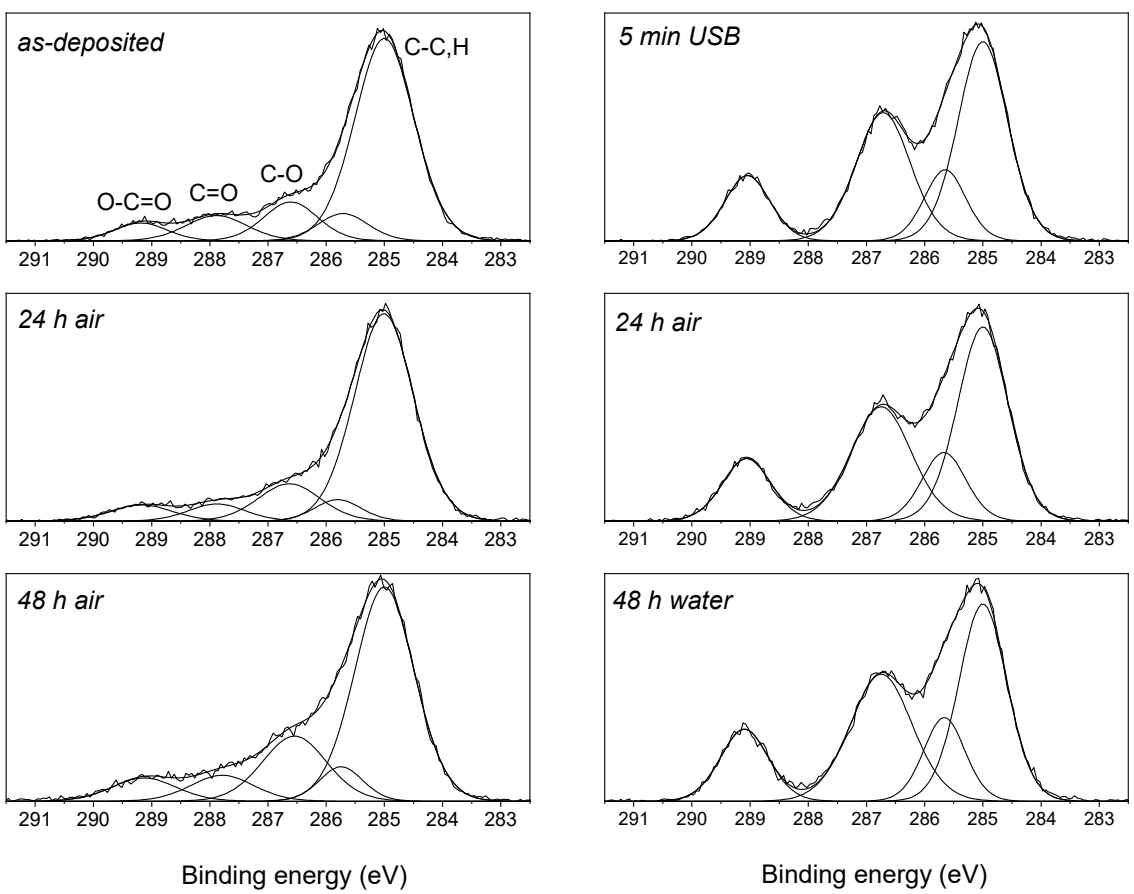

Figure 7. X-ray photoelectron spectroscopy (XPS) high-resolution C 1s spectra, including the peak-fit of HEMA-based polymer films as deposited after 5 min of USB, stored in air or in deionized water for $24 \mathrm{~h}$ and $48 \mathrm{~h}$, respectively.

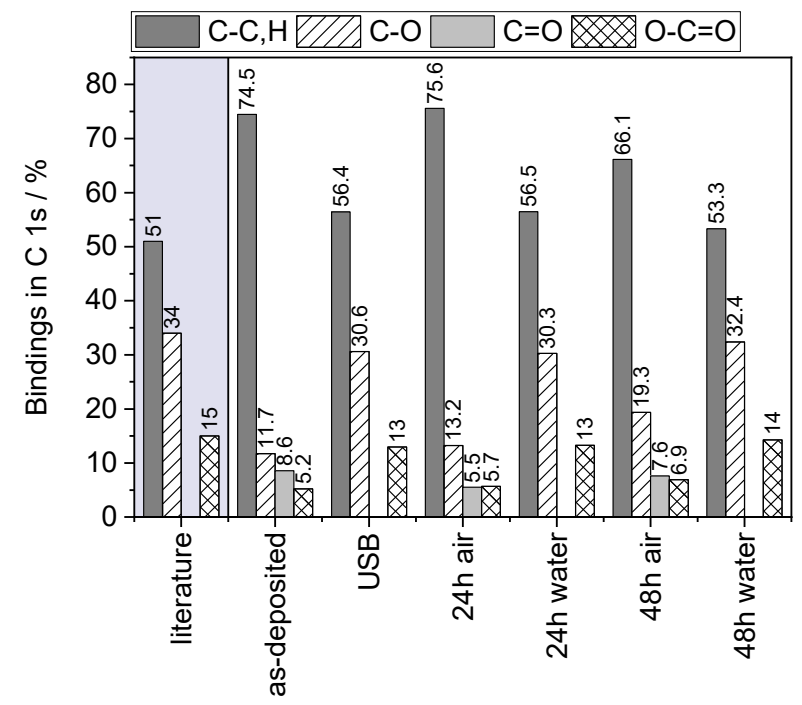

Figure 8. Functional group distribution of the coatings determined from XPS high-resolution C $1 \mathrm{~s}$ spectra. Data obtained from the literature are based on [59].

To investigate the elemental and chemical distributions at greater depths, destructive XPS depth profiling was performed in the center of the coating by sputtering with a large Ar cluster ion beam. In this approach, Ar cluster ions (10 keV beam energy) were used to etch a few nanometers of the sample surface. The elemental depth profiles were determined by sequential measurements of the elemental intensities after each sputter cycle. In Figure 9A, the XPS depth profile of the HEMA-based film, deposited on titanium, is depicted. It was found that the elemental composition near the surface and in the bulk of the coating was comparable. Furthermore, high-resolution $C$ 1s spectra were recorded at regular intervals during depth profiling, shown in Figure 9B. According to the bindings in C1s, quantified from the corresponding peak-fit, differences could be seen when comparing 
the near-surface region and the bulk. On top of the coating, $\mathrm{C}=\mathrm{O}$ groups were present, which disappeared immediately after the first sputter cycle. More precisely, three distinct chemical environments were detected in the $C 1$ s spectrum, with a hydrocarbon peak at $285.0 \mathrm{eV}$, a carbon singly bonded to oxygen peak at $286.8 \mathrm{eV}$ and a peak assigned to the ester group at $289.2 \mathrm{eV}$. Deduced from the depth profile, the chemical structure of the coating was found to be conserved throughout the film to the sample-substrate interface.
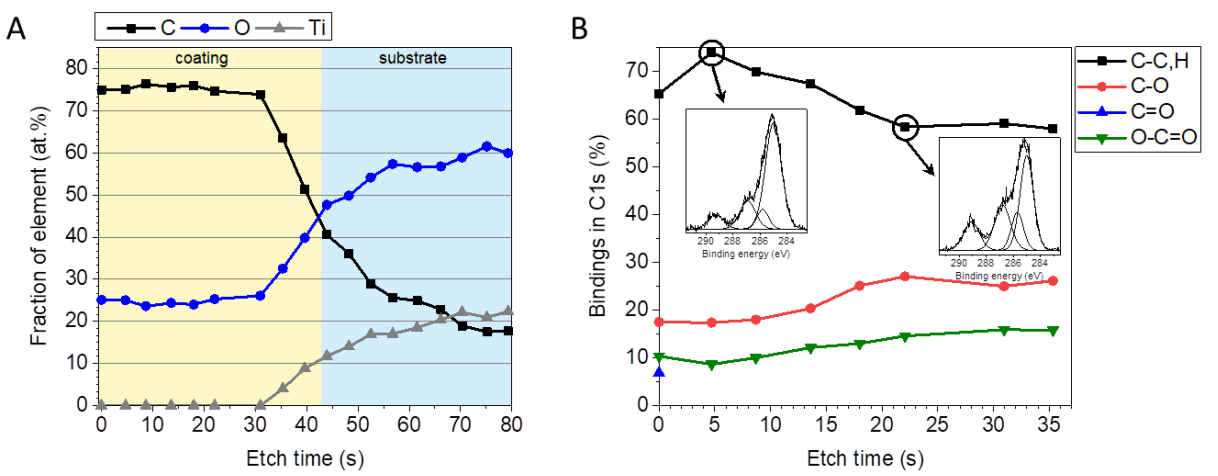

Figure 9. XPS depth profile from the Ar cluster-etched (10 keV $\mathrm{Ar}_{1000}+$ ) HEMA-based polymer film, showing C 1s, $\mathrm{O}$ 1s and Ti 2p signals, depending on the etch time (A) and functional group distribution determined from the corresponding high-resolution C 1s spectra (B).

\subsection{Biocompatibility}

\subsubsection{Indirect Cytotoxicity}

No toxic effects were observed on the hFFs in contact with the eluents of the samples (Figure 10), with cell viabilities above $80 \%$ in all cases. This fact shows that during the plasma process, no toxic molecules were produced or, if they were, the concentration was too low to exert cell toxicity.

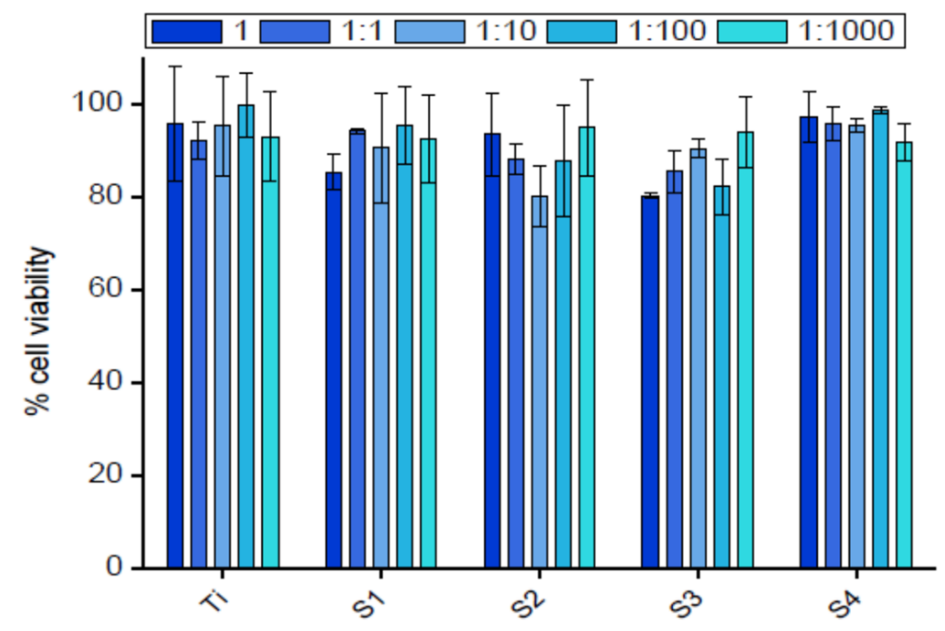

Figure 10. Cell viability of hFFs on the different surfaces, with respect to the control (Ti) in the indirect cytotoxicity test. No statistically significant differences between the conditions were found.

\subsubsection{Cell Adhesion}

The adhesion of the hFFs was tested after $6 \mathrm{~h}$ and $24 \mathrm{~h}$ in contact with the coated samples (Figure 11),. The assay revealed higher adhesion on the plasma-polymerized HEMA samples than on titanium. Regarding the cell proliferation after $24 \mathrm{~h}$, the increase of the cell number was higher on the titanium than on the coated samples in most conditions. 


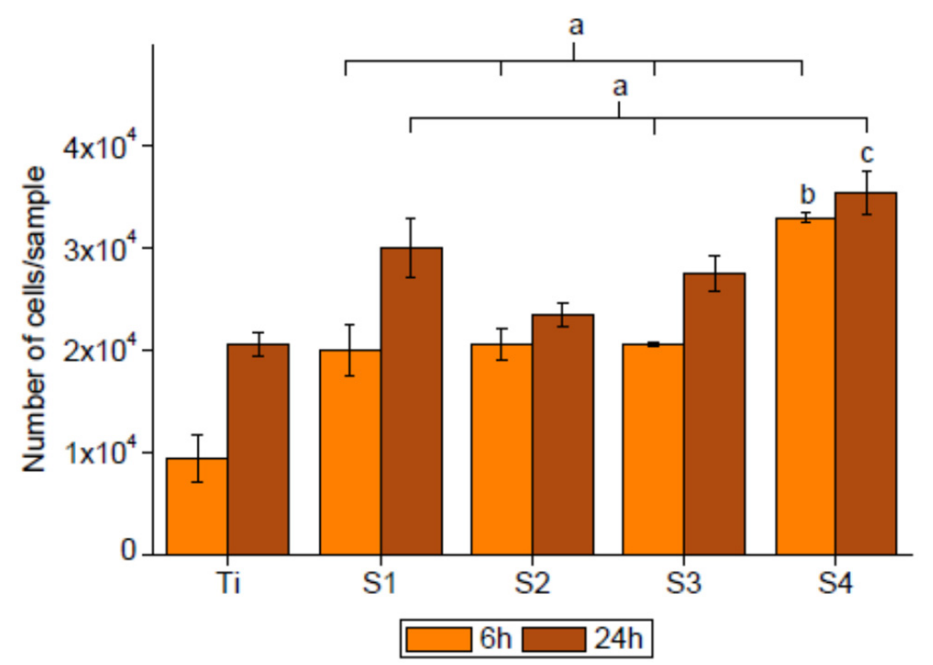

Figure 11. Adhesion of hFFs on the plasma-polymerized, HEMA-coated samples. For each time point, a indicates statistically significant differences compared with Ti, b compared with S1, S2 and S3 and c compared with S2 and S3 $(p<0.05)$.

\subsection{Bacterial Adhesion}

Figure 12 presents the colony forming units (CFUs) of E. coli and S. aureus, incubated for $2 \mathrm{~h}$ on HEMA-coated Ti substrates. The bacterial adhesion of S. aureus and E. coli was lower on the plasma-polymerized, HEMA-based coatings. It was found that the adhesion of $E$. coli was reduced up to $50 \%$ for the coated samples compared with pristine Ti. Similar results were obtained for $S$. aureus, which displayed around $50 \%$ lower adhesion than the control surface, except S4, which was slightly less efficient with only a $75 \%$ reduction in bacterial adhesion with respect to the control.
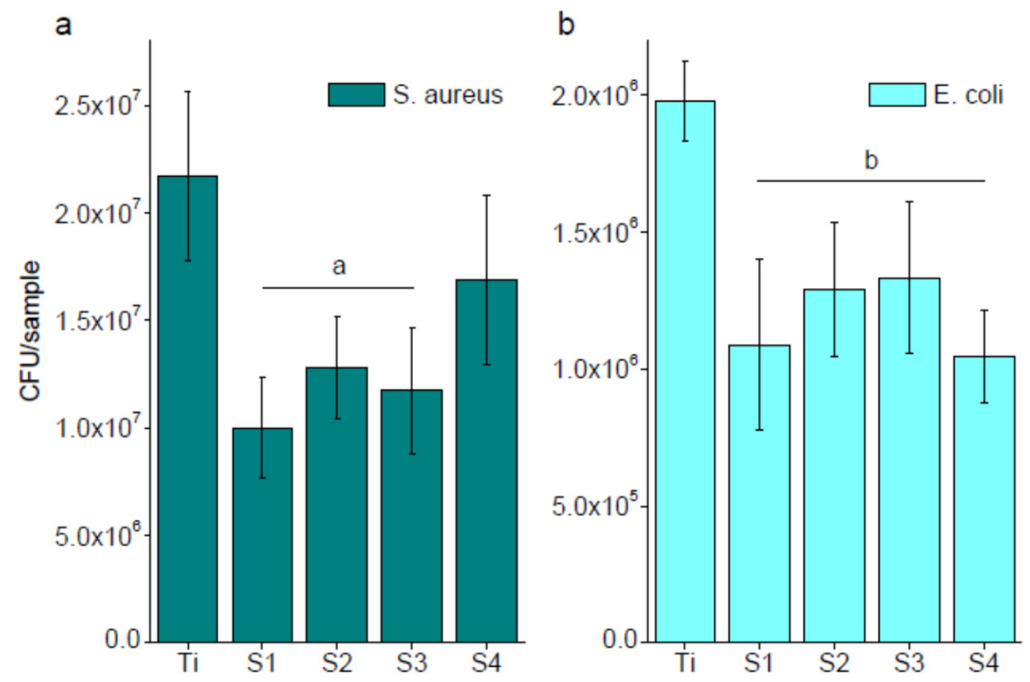

Figure 12. S. aureus (a) and E. coli (b) adhesion on plasma-polymerized HEMA samples. $a$ indicates statistically significant differences compared with $\mathrm{Ti}$ in the $S$. aureus assay, and $b$ indicates statistically significant differences compared with Ti in the E. coli assay. $(p<0.05)$.

\section{Discussion}

An atmospheric pressure plasma jet was used for the polymerization of liquid-phase HEMA to generate acrylate-based coatings on titanium substrates. The chemical compositions, wetting properties and stability of the coatings deposited at different process conditions were investigated. The coatings obtained showed hydrophilic surface properties with a similar chemical composition when compared to the original precursor. The coatings' 
surface free energy was more than twofold higher than that of pristine titanium, resulting in an improved wettability. Similar results were found in previous studies for PHEMA coatings [60], with a higher polar component and a lower dispersive component. This fact indicates that the coatings presented here had a higher amount of polar groups when compared with other methods employed to synthesize HEMA-based polymer films. The higher wettability enhances the suitability of the coating for biomedical applications [61,62].

Regarding the chemical analysis by ATR-FTIR, the main peaks of a PHEMA coating could be detected [63]. The elemental compositions of the coatings, determined by XPS, are comparable to the one reported by other authors for PHEMA coatings, obtained by plasma polymerization $[64,65]$, and they are similar to the theoretical one of the precursor (67\% carbon, 33\% oxygen). However, the stoichiometry of the different carbon-oxygen bonds is slightly different to the theoretical one, indicating that some changes on these functionalities might have occurred during the plasma treatment. The stability studies showed that the coating was stable after being stored in air and immersed in water. This can be associated with the formation of a chemical bond between the polymer and the substrate during the plasma treatment.

No toxicity was observed in the in vitro cytotoxicity assay, with a cell viability above $80 \%$ for all samples. It has been reported that HEMA exerts cell toxicity via apoptosiss, among other effects [66-68]. In contrast, its polymerized counterpart, PHEMA, is biocompatible and has no toxic effects $[69,70]$. From the results obtained in this study, it can be concluded that the HEMA precursor was polymerized during the plasma treatment, at least to the extent that the toxicity effect was not observed. Moreover, an indicator of the stability of the coating can also be extracted from these results, since no changes in the cell viability were observed after its immersion in a cell culture medium for $72 \mathrm{~h}$.

The hFF adhesion on the HEMA-based coatings was higher than the control, indicating the possibility of better tissue integration around the material. Even though PHEMA coatings have been reported to be antifouling and reduce the protein adsorption and cell adhesion [65], there are also reports regarding the ability of such coatings to allow cell adhesion [60]. Moreover, some modifications of the coatings, such as UV cross-linking, can impart chemical functionalities which enhance cell adhesion [71]. In the case of fibroblasts, a good adhesion brings forward the possibility of optimum biosealing around the implant, which further avoids bacterial infiltration and infection [72,73]. The sealing has been also observed to be promoted by the lower bacterial adhesion, both of E. coli and S. aureus, in similar coatings $[35,74,75]$. This is due to the water retention of the coating, which in turn produces an antifouling effect, reducing the number of bacteria adhered. Similar results were observed with coatings obtained in low-pressure plasma systems. For example, Cökelier et al. [76] found a reduction of $62 \%$ in the adhesion of Staphylococcus epidermidis when applying the HEMA coating, and Alves et al. [32] found an inhibition of the biofilm formation of E. coli when in contact with a HEMA coating.

\section{Conclusions}

A plasma-polymerized, HEMA-based coating has been successfully prepared by treating the liquid monomer with an atmospheric pressure plasma jet. The coating showed retained wettability and chemical composition compared with the precursor. While part of the coating was lost after stability treatments, the remaining coating displayed sufficient stability after immersion in deionized water or ultrasonication. Fibroblast adhesion was enhanced due to the oxygen-rich polymer film, while the bacterial adhesion of both S. aureus and $E$. coli was reduced to $50 \%$, as compared with the control sample. These promising results indicate that HEMA-based coatings may have a future in clinical applications of titanium in dentistry. 
Author Contributions: Conceptualization, K.F., S.R. and C.C.; methodology, K.F. and S.R.; investigation, J.B.-P. and K.F.; resources, C.C., D.R., F.J.G. and S.R.; writing-original draft preparation, J.B.-P. and K.F.; writing-review and editing, C.C., D.R., F.J.G., S.R. and K.F.; project administration, C.C.; funding acquisition, C.C., D.R., F.J.G. and S.R. All authors have read and agreed to the published version of the manuscript.

Funding: This article is based upon work from COST Action TD1208, supported by COST (European Cooperation in Science and Technology). The authors acknowledge MINECO for their support through project PID2019-103892RB-I00 and projects RTI2018-098075-B-C21 and MAT2017-83905-R, co-funded by the EU through European Regional Development Funds. SR acknowledges funding by the German Ministry of Education and Research (BMBF, grant number 03Z2DN12). Data discussion and manuscript editing was performed during funding within the TransMedTech Institute by the Canada First Research Excellence Fund and Fonds de Recherche du Quebec (S.R.).

Institutional Review Board Statement: Not applicable.

Informed Consent Statement: Not applicable.

Data Availability Statement: Not applicable.

Conflicts of Interest: The authors declare no conflict of interest.

\section{References}

1. Steinemann, S.G. Titanium-The material of choice? Periodontol. 2000 1998, 17, 7-21. [CrossRef] [PubMed]

2. Sakka, S.; Coulthard, P. Implant failure: Etiology and complications. Med. Oral Patol. Oral Cir. Bucal 2011, 16, 42-44. [CrossRef] [PubMed]

3. Kronström, M.; Svenson, B.; Hellman, M.; Persson, G.R. Early implant failures in patients treated with Brånemark System titanium dental implants: A retrospective study. Int. J. Oral Maxillofac. Implants 2001, 16, 201-207. [PubMed]

4. Ong, C.T.T.; Ivanovski, S.; Needleman, I.G.; Retzepi, M.; Moles, D.R.; Tonetti, M.S.; Donos, N. Systematic review of implant outcomes in treated periodontitis subjects. J. Clin. Periodontol. 2008, 35, 438-462. [CrossRef] [PubMed]

5. Mouhyi, J.; Dohan Ehrenfest, D.M.; Albrektsson, T. The peri-implantitis: Implant surfaces, microstructure, and physicochemical aspects. Clin. Implant Dent. Relat. Res. 2012, 14, 170-183. [CrossRef] [PubMed]

6. Mavrogenis, A.F.; Dimitriou, R.; Parvizi, J.; Babis, G.C. Biology of implant osseointegration. J. Musculoskelet. Neuronal Interact. 2009, 9, 61-71. [PubMed]

7. Bryant, S.R.; Zarb, G.A. Osseointegration of oral implants in older and younger adults. Int. J. Oral Maxillofac. Implants 2015, 13, 492-499.

8. Parithimarkalaignan, S.; Padmanabhan, T.V. Osseointegration: An update. J. Indian Prosthodont. Soc. 2013, 13, 2-6. [CrossRef]

9. Ogle, O.E. Implant Surface Material, Design, and Osseointegration. Dent. Clin. N. Am. 2015, 59, 505-520. [CrossRef]

10. W. Nicholson, J. Titanium Alloys for Dental Implants: A Review. Prosthesis 2020, 2, 100-116. [CrossRef]

11. Bollen, C.M.; Lambrechts, P.; Quirynen, M. Comparison of surface roughness of oral hard materials to the threshold surface roughness for bacterial plaque retention: A review of the literature. Dent. Mater. 1997, 13, 258-269. [CrossRef]

12. Godoy-Gallardo, M.; Rodríguez-Hernández, A.G.; Delgado, L.M.; Manero, J.M.; Javier Gil, F.; Rodríguez, D. Silver deposition on titanium surface by electrochemical anodizing process reduces bacterial adhesion of Streptococcus sanguinis and Lactobacillus salivarius. Clin. Oral Implants Res. 2014, 26, 1-10. [CrossRef]

13. Bosetti, M.; Massè, A.; Tobin, E.; Cannas, M. Silver coated materials for external fixation devices: In vitro biocompatibility and genotoxicity. Biomaterials 2002, 23, 887-892. [CrossRef]

14. Melaiye, A.; Youngs, W.J. Silver and its application as an antimicrobial agent. Expert Opin. Ther. Pat. 2005, 15, 125-130. [CrossRef]

15. Tian, X.B.; Wang, Z.M.; Yang, S.Q.; Luo, Z.J.; Fu, R.K.Y.; Chu, P.K. Antibacterial copper-containing titanium nitride films produced by dual magnetron sputtering. Surf. Coat. Technol. 2007, 201, 8606-8609. [CrossRef]

16. Yoshinari, M.; Oda, Y.; Kato, T.; Okuda, K. Influence of surface modifications to titanium on antibacterial activity in vitro. Biomaterials 2001, 22, 2043-2048. [CrossRef]

17. Tsuchiya, H.; Shirai, T.; Nishida, H.; Murakami, H.; Kabata, T.; Yamamoto, N.; Watanabe, K.; Nakase, J. Innovative antimicrobial coating of titanium implants with iodine. J. Orthop. Sci. 2012, 17, 595-604. [CrossRef]

18. Zhurakivska, K.; Ciacci, N.; Troiano, G.; Caponio, V.C.A.; Scrascia, R.; Pallecchi, L.; Lo Muzio, L.; Arena, F. Nitride-Coated and Anodic-Oxidized Titanium Promote a Higher Fibroblast and Reduced Streptococcus gordonii Proliferation Compared to the Uncoated Titanium. Prosthesis 2020, 2, 333-339. [CrossRef]

19. Radin, S.; Ducheyne, P. Controlled release of vancomycin from thin sol-gel films on titanium alloy fracture plate material. Biomaterials 2007, 28, 1721-1729. [CrossRef]

20. Stigter, M.; De Groot, K.; Layrolle, P. Incorporation of Tobramycin into biomimetic hydroxyapatite coating on titanium. Biomaterials 2002, 23, 4143-4153. [CrossRef] 
21. Kazemzadeh-Narbat, M.; Kindrachuk, J.; Duan, K.; Jenssen, H.; Hancock, R.E.W.; Wang, R. Antimicrobial peptides on calcium phosphate-coated titanium for the prevention of implant-associated infections. Biomaterials 2010, 31, 9519-9526. [CrossRef] [PubMed]

22. Gabriel, M.; Nazmi, K.; Veerman, E.C.; Nieuw Amerongen, A.V.; Zentner, A. Preparation of LL-37-grafted titanium surfaces with bactericidal activity. Bioconjug. Chem. 2006, 17, 548-550. [CrossRef] [PubMed]

23. Costa, F.; Carvalho, I.F.; Montelaro, R.C.; Gomes, P.; Martins, M.C.L. Covalent immobilization of antimicrobial peptides (AMPs) onto biomaterial surfaces. Acta Biomater. 2011, 7, 1431-1440. [CrossRef] [PubMed]

24. Hoyos-Nogués, M.; Buxadera-Palomero, J.; Ginebra, M.P.; Manero, J.M.; Gil, F.J.; Mas-Moruno, C. All-in-one trifunctional strategy: A cell adhesive, bacteriostatic and bactericidal coating for titanium implants. Colloids Surf. B Biointerfaces 2018, 169, 30-40. [CrossRef]

25. Koopaie, M.; Bordbar-Khiabani, A.; Kolahdooz, S.; Darbandsari, A.K.; Mozafari, M. Advanced surface treatment techniques counteract biofilm-associated infections on dental implants. Mater. Res. Express 2020, 7, 015417. [CrossRef]

26. Raphel, J.; Holodniy, M.; Goodman, S.B.; Heilshorn, S.C. Multifunctional coatings to simultaneously promote osseointegration and prevent infection of orthopaedic implants. Biomaterials 2016, 84, 301-314. [CrossRef]

27. Campoccia, D.; Montanaro, L.; Arciola, C.R. A review of the biomaterials technologies for infection-resistant surfaces. Biomaterials 2013, 34, 8533-8554. [CrossRef]

28. Buxadera-Palomero, J.; Albó, K.; Gil, F.J.; Mas-Moruno, C.; Rodríguez, D. Polyethylene Glycol Pulsed Electrodeposition for the Development of Antifouling Coatings on Titanium. Coatings 2020, 10, 456. [CrossRef]

29. Buxadera-Palomero, J.; Calvo, C.; Torrent-Camarero, S.; Gil, F.J.; Mas-Moruno, C.; Canal, C.; Rodríguez, D. Biofunctional polyethylene glycol coatings on titanium: An in vitro-based comparison of functionalization methods. Colloids Surf. B Biointerfaces 2017, 152. [CrossRef]

30. Banerjee, I.; Pangule, R.C.; Kane, R.S. Antifouling coatings: Recent developments in the design of surfaces that prevent fouling by proteins, bacteria, and marine organisms. Adv. Mater. 2011, 23, 690-718. [CrossRef]

31. Gour, N.; Ngo, K.X.; Vebert-Nardin, C. Anti-Infectious Surfaces Achieved by Polymer Modification. Macromol. Mater. Eng. 2014, 299, 648-668. [CrossRef]

32. Alves, P.; Cardoso, R.; Correia, T.R.; Antunes, B.P.; Correia, I.J.; Ferreira, P. Surface modification of polyurethane films by plasma and ultraviolet light to improve haemocompatibility for artificial heart valves. Colloids Surf. B. Biointerfaces 2014, 113, 25-32. [CrossRef] [PubMed]

33. Veuillet, M.; Ploux, L.; Airoudj, A.; Gourbeyre, Y.; Gaudichet-Maurin, E.; Roucoules, V. Macroscopic control of DMAHEMA and HEMA plasma polymerization to tune the surface mechanical properties of hydrogel-like coatings. Plasma Process. Polym. 2017, 14, 1600215. [CrossRef]

34. Vieira, A.P.; Pimenta, A.F.R.; Silva, D.; Gil, M.H.; Alves, P.; Coimbra, P.; Mata, J.L.G.C.; Bozukova, D.; Correia, T.R.; Correia, I.J.; et al. Surface modification of an intraocular lens material by plasma-assisted grafting with 2-hydroxyethyl methacrylate (HEMA), for controlled release of moxifloxacin. Eur. J. Pharm. Biopharm. 2017, 120, 52-62. [CrossRef] [PubMed]

35. Sabine, P.; Dirk, V.; Olivier, G.; Erik, D. Antimicrobial Coatings Obtained in an Atmospheric Pressure Dielectric Barrier Glow Discharge. MRS Proc. 2002, 724, N8.13. [CrossRef]

36. Jalaber, V.; Del Frari, D.; De Winter, J.; Mehennaoui, K.; Planchon, S.; Choquet, P.; Detrembleur, C.; Moreno-Couranjou, M. Atmospheric Aerosol Assisted Pulsed Plasma Polymerization: An Environmentally Friendly Technique for Tunable CatecholBearing Thin Films. Front. Chem. 2019, 7, 183. [CrossRef]

37. Doherty, K.G.; Oh, J.-S.; Unsworth, P.; Sheridan, C.M.; Weightman, P.; Bradley, J.W.; Williams, R.L. Plasma polymerization using helium atmospheric-pressure plasma jet with heptylamine monomer. Plasma Process. Polym. 2019, 16, e1800185. [CrossRef]

38. Lo Porto, C.; Palumbo, F.; Buxadera-Palomero, J.; Canal, C.; Jelinek, P.; Zajickova, L.; Favia, P. On the plasma deposition of vancomycin-containing nano-capsules for drug-delivery applications. Plasma Process. Polym. 2018. [CrossRef]

39. Bitar, R.; Cools, P.; De Geyter, N.; Morent, R. Acrylic acid plasma polymerization for biomedical use. Appl. Surf. Sci. 2018, 448, 168-185. [CrossRef]

40. Mussano, F.; Genova, T.; Verga Falzacappa, E.; Scopece, P.; Munaron, L.; Rivolo, P.; Mandracci, P.; Benedetti, A.; Carossa, S.; Patelli, A. In vitro characterization of two different atmospheric plasma jet chemical functionalizations of titanium surfaces. Appl. Surf. Sci. 2017, 409, 314-324. [CrossRef]

41. Pandiyaraj, K.N.; Arun Kumar, A.; RamKumar, M.C.; Padmanabhan, P.V.A.; Trimukhe, A.M.; Deshmukh, R.R.; Cools, P.; Morent, R.; De Geyter, N.; Kumar, V.; et al. Influence of operating parameters on development of polyethylene oxide-like coatings on the surfaces of polypropylene films by atmospheric pressure cold plasma jet-assisted polymerization to enhance their antifouling properties. J. Phys. Chem. Solids 2018, 123, 76-86. [CrossRef]

42. Kung, F.C.; Kuo, Y.L.; Gunduz, O.; Lin, C.C. Dual RGD-immobilized poly(L-lactic acid) by atmospheric pressure plasma jet for bone tissue engineering. Colloids Surf. B Biointerfaces 2019, 178, 358-364. [CrossRef] [PubMed]

43. Lee, M.J.; Kwon, J.S.; Jiang, H.B.; Choi, E.H.; Park, G.; Kim, K.M. The antibacterial effect of non-thermal atmospheric pressure plasma treatment of titanium surfaces according to the bacterial wall structure. Sci. Rep. 2019, 9, 1-13. [CrossRef]

44. Gupta, T.T.; Karki, S.B.; Matson, J.S.; Gehling, D.J.; Ayan, H. Sterilization of Biofilm on a Titanium Surface Using a Combination of Nonthermal Plasma and Chlorhexidine Digluconate. Biomed. Res. Int. 2017, 2017. [CrossRef] 
45. Patelli, A.; Mussano, F.; Brun, P.; Genova, T.; Ambrosi, E.; Michieli, N.; Mattei, G.; Scopece, P.; Moroni, L. Nanoroughness, Surface Chemistry, and Drug Delivery Control by Atmospheric Plasma Jet on Implantable Devices. ACS Appl. Mater. Interfaces 2018, 10, 39512-39523. [CrossRef]

46. Chen, L.; Yan, C.; Zheng, Z. Functional polymer surfaces for controlling cell behaviors. Mater. Today 2018, 21, 38-59. [CrossRef]

47. Nisol, B.; Oldenhove, G.; Preyat, N.; Monteyne, D.; Moser, M.; Perez-Morga, D.; Reniers, F. Atmospheric plasma synthesized PEG coatings: Non-fouling biomaterials showing protein and cell repulsion. Surf. Coat. Technol. 2014, 252, 126-133. [CrossRef]

48. Özden, N.; Ayhan, H.; Erkut, S.; Can, G.; Piskin, E. Coating of silicone-based impression materials in a glow-discharge system by acrylic acid plasma. Dent. Mater. 1997, 13, 174-178. [CrossRef]

49. Labay, C.; Canal, J.M.; Modic, M.; Cvelbar, U.; Quiles, M.; Armengol, M.; Arbos, M.A.; Gil, F.J.; Canal, C. Antibiotic-loaded polypropylene surgical meshes with suitable biological behaviour by plasma functionalization and polymerization. Biomaterials 2015, 71, 132-144. [CrossRef]

50. Fernández, I.C.S.; Van der Mei, H.C.; Metzger, S.; Grainger, D.W.; Engelsman, A.F.; Nejadnik, M.R.; Busscher, H.J. In vitro and in vivo comparisons of staphylococcal biofilm formation on a cross-linked poly(ethylene glycol)-based polymer coating. Acta Biomater. 2010, 6, 1119-1124. [CrossRef]

51. Buxadera-Palomero, J.; Canal, C.; Torrent-Camarero, S.; Garrido, B.; Javier Gil, F.J.; Rodríguez, D. Antifouling coatings for dental implants: Polyethylene glycol-like coatings on titanium by plasma polymerization. Biointerphases 2015, 10. [CrossRef] [PubMed]

52. Chen, M.; Zhang, Y.; Dusevich, V.; Liu, Y.; Yu, Q.; Wang, Y. Non-thermal atmospheric plasma brush induces HEMA grafting onto dentin collagen. Dent. Mater. 2014, 30, 1369-1377. [CrossRef] [PubMed]

53. Levien, M.; Fricke, K. Fabrication of hydrogel coatings by atmospheric-pressure plasma polymerization: Function by structure and chemistry. Mater. Today 2020. [CrossRef]

54. Schäfer, J.; Foest, R.; Ohl, A.; Weltmann, K.-D. Miniaturized non-thermal atmospheric pressure plasma jet-characterization of self-organized regimes. Plasma Phys. Control. Fusion 2009, 51, 124045. [CrossRef]

55. Owens, D.K.; Wendt, R.C. Estimation of the surface free energy of polymers. J. Appl. Polym. Sci. 1969, 13, 1741-1747. [CrossRef]

56. ISO. ISO 10993-5: 2009. Biological Evaluation of Medical Devices-Part 5: Tests for In Vitro Cytotoxicity. 2009. Available online: https: / / www.iso.org/standard/36406.html (accessed on 8 January 2021).

57. Helena Martin-Gómez, H.; Oliver-Cervelló, L.; Buxadera-Palomero, J.; Ginebra, M.-P.; Mas-Moruno, C. Chemically Diverse Multifunctional Peptide Platforms with Antimicrobial and Cell Adhesive Properties. Chembiochem 2020. [CrossRef]

58. Castner, D.G.; Ratner, B.D. Surface characterization of butyl methacrylate polymers by XPS and static SIMS. Surf. Interface Anal. 1990, 15, 479-486. [CrossRef]

59. Beamson, G.; Briggs, D. High Resolution XPS of Organic Polymers: The Scienta ESCA300 Database (Beamson, G.; Briggs, D.). J. Chem. Educ. 1993, 70, A25. [CrossRef]

60. De Giglio, E.; Cafagna, D.; Giangregorio, M.; Domingos, M.; Mattioli-Belmonte, M.; Cometa, S. PHEMA-based thin hydrogel films for biomedical applications. J. Bioact. Compat. Polym. 2011, 26, 420-434. [CrossRef]

61. Bavaresco, V.P.; Zavaglia, C.A.C.; Malmonge, S.M.; Reis, M.C. Viability of pHEMA Hydrogels as Coating in Human Synovial Joint Prosthesis. Mater. Res. 2002, 5, 481-484. [CrossRef]

62. Indolfi, L.; Causa, F.; Netti, P.A. Coating process and early stage adhesion evaluation of poly(2-hydroxy-ethyl-methacrylate) hydrogel coating of 316L steel surface for stent applications. J. Mater. Sci. Mater. Med. 2009, 20, 1541-1551. [CrossRef] [PubMed]

63. Perova, T.S.; Vij, J.K.; Xu, H. Fourier transform infrared study of poly (2-hydroxyethyl methacrylate) PHEMA. Colloid Polym. Sci. 1997, 275, 323-332. [CrossRef]

64. Valdes, T.I.; Ciridon, W.; Ratner, B.D.; Bryers, J.D. Surface modification of a perfluorinated ionomer using a glow discharge deposition method to control protein adsorption. Biomaterials 2008, 29, 1356-1366. [CrossRef] [PubMed]

65. Mrabet, B.; Nguyen, M.N.; Majbri, A.; Mahouche, S.; Turmine, M.; Bakhrouf, A.; Chehimi, M.M. Anti-fouling poly(2-hydoxyethyl methacrylate) surface coatings with specific bacteria recognition capabilities. Surf. Sci. 2009, 603, 2422-2429. [CrossRef]

66. Gallorini, M.; Cataldi, A.; di Giacomo, V. HEMA-induced cytotoxicity: Oxidative stress, genotoxicity and apoptosis. Int. Endod. J. 2014, 47, 813-818. [CrossRef]

67. Bakopoulou, A.; Papadopoulos, T.; Garefis, P. Molecular Toxicology of Substances Released from Resin-Based Dental Restorative Materials. Int. J. Mol. Sci. 2009, 10, 3861-3899. [CrossRef]

68. Krifka, S.; Spagnuolo, G.; Schmalz, G.; Schweikl, H. A review of adaptive mechanisms in cell responses towards oxidative stress caused by dental resin monomers. Biomaterials 2013, 34, 4555-4563. [CrossRef]

69. Ertel, S.I.; Ratner, B.D.; Kaul, A.; Schway, M.B.; Horbett, T.A. In vitro study of the intrinsic toxicity of synthetic surfaces to cells. J. Biomed. Mater. Res. 1994, 28, 667-675. [CrossRef]

70. Prasitsilp, M.; Siriwittayakorn, T.; Molloy, R.; Suebsanit, N.; Siriwittayakorn, P.; Veeranondha, S. Cytotoxicity study of homopolymers and copolymers of 2-hydroxyethyl methacrylate and some alkyl acrylates for potential use as temporary skin substitutes. J. Mater. Sci. Mater. Med. 2003, 14, 595-600. [CrossRef]

71. Wang, J.; Karami, P.; Ataman, N.C.; Pioletti, D.P.; Steele, T.W.J.; Klok, H.-A. Light-Activated, Bioadhesive, Poly(2-hydroxyethyl methacrylate) Brush Coatings. Biomacromolecules 2020, 21, 240-249. [CrossRef]

72. Myshin, H.L.; Wiens, J.P. Factors affecting soft tissue around dental implants: A review of the literature. J. Prosthet. Dent. 2005, 94, 440-444. [CrossRef] [PubMed] 
73. Sculean, A.; Gruber, R.; Bosshardt, D.D. Soft tissue wound healing around teeth and dental implants. J. Clin. Periodontol. 2014, 41 (Suppl. 1), S6-S22. [CrossRef] [PubMed]

74. Kiremitçi-Gümü, M. Microbial adhesion to ionogenic PHEMA, PU and PP implants. Biomaterials 1996, 17, 443-449. [CrossRef]

75. Lim, H.; Lee, Y.; Han, S.; Cho, J.; Kim, K.-J. Surface treatment and characterization of PMMA, PHEMA, and PHPMA. J. Vac. Sci. Technol. A Vac. Surf. Film. 2001, 19, 1490-1496. [CrossRef]

76. Çökeliler, D.; Caner, H.; Zemek, J.; Choukourov, A.; Biederman, H.; Mutlu, M. A plasma polymerization technique to overcome cerebrospinal fluid shunt infections. Biomed. Mater. 2007, 2, 39-47. [CrossRef] 